\title{
Prospective analysis of ambiental and weather effects on conform displaying of fireworks
}

\author{
Ciprian Jitea ${ }^{1, *}$, Attila Kovacs $^{1}$, Gabriel Vasilescu ${ }^{1}$, Edward Gheorghiosu ${ }^{1}$, Daniela Rus ${ }^{1}$, \\ and Sorin Bordoș ${ }^{1}$ \\ ${ }^{1}$ National Institute for Research and Development in Mine Safety and Protection to Explosion - \\ INSEMEX Petroșani, 32-34 G-ral Vasile Milea Street, Postcode: 332047, Petroșani, Hunedoara \\ County, Romania
}

\begin{abstract}
The paper presents the results of research on theoretical and practical relating to establishing and analysis of effects of ambiental and weather effects on conform displaying of fireworks used to organizing fireworks. Scientific research highlighted in this article was conducted in the project no. PN 16430304 , study conducted through Nucleu program entitled -,, Research on the influence of microclimate factors on parameters of the products, while testing the functioning of pyrotechnic articles ".
\end{abstract}

\section{Introduction}

Pyrotechnic articles are under classification of dangerous products, risk Class 1 - explosives. At European and national level is in force the Directive 2013/29 / EU of the European Parliament and of the Council of June 12, 2013 respectively Decision of Romanian Government no. 1102 of 10 December 2014 laying down conditions making available on the market of pyrotechnic articles. In these documents are established the essential safety requirements to which these products must meet. Essential safety requirements be taken into account on the one hand in the design and manufacturing of products and tests and assessment by third party entities (products certification body and accredited laboratory). In case of complies and suspicions on conformity the market surveillance authorities may require additional repetition of such tests. Depending on the type and category of pyrotechnic articles usually should check their conformity by application of harmonized European standards which specific test methods with all the technical and organizational measures.

The paper highlights the degree of improvement the infrastructure on test of pyrotechnic articles (fireworks) whose attempt to apply the SR EN 15947-4: 2016 - Pyrotechnic articles. Fireworks, Categories F1, F2 and F3. Part 4: Test methods SR EN 16261-3: 2013 Pyrotechnic articles. Fireworks, Category 4. Part 3: Test methods. The Directive states that attempts to use products under conditions that reproduce as closely is possible as, the real ones that can meet in their use. The project has in view products whose intended use is specified in the safety data sheet, that instructions are known within the parameters of microclimate that can meet (temperature, humidity, wind - for those used outside, respectively that with inside use temperature, humidity, generating toxic fumes).

* Corresponding author: ciprian.jitea@insemex.ro 
In this respect a modern "Equipment for professional monitoring and recording microclimate parameters, allows simultaneous management of all micro - climate factors which are variable and their unusual effects can affect health and safety requirements, comparative to the normal expected values [1-2]. Also, compliance with regulatory technical requirements and test procedures led to improved technical and qualitative level to perform the functioning test of the pyrotechnic articles, regarding the influence of micro climate and the possibilities to conduct tests operation with automated data processing results.

\section{Material and Method}

Establishing the specific functional parameters of fireworks that may be affected by ambiental and weather effects. European Directive provides that tests of products to be done under conditions that replicate as closely as real ones which can meet on their use. Being products whose intended use it is specified in the safety data sheet respectively instructions for use are known the limits of micro-climate that may be encountered (temperature, humidity, wind - for the outdoor respectively temperature, humidity, generation of toxic compounds, to the indoor use).

Products intended for interior can be considered as being banal, whereas usually factors contained are not exceptional in use $\left(20 \pm 40^{\circ} \mathrm{C}\right.$, relative humidity 60 to $80 \%$ fairly ordinary, unnoticeable air currents, excluding compounds from burning pyrotechnic composition which generates toxic agents). The situation of fireworks from category F2, F3 respectively F4 it is very variable which means micro-climate conditions in which is used respectively product is tested for assessments. [3-4]

The purchase of a performant multifunction device for monitoring and recording parameters of microclimate with incorporated software according to European applicable harmonized standards.

In order to implement an integrated and comprehensive solutions to ensure the measurements and determinations of fireworks displaying (F1, F2, F3 and F4) under conditions of high accuracy in accordance with standards methods applied, a multifunctional equipment was purchased, as can be seen from figure 1 .

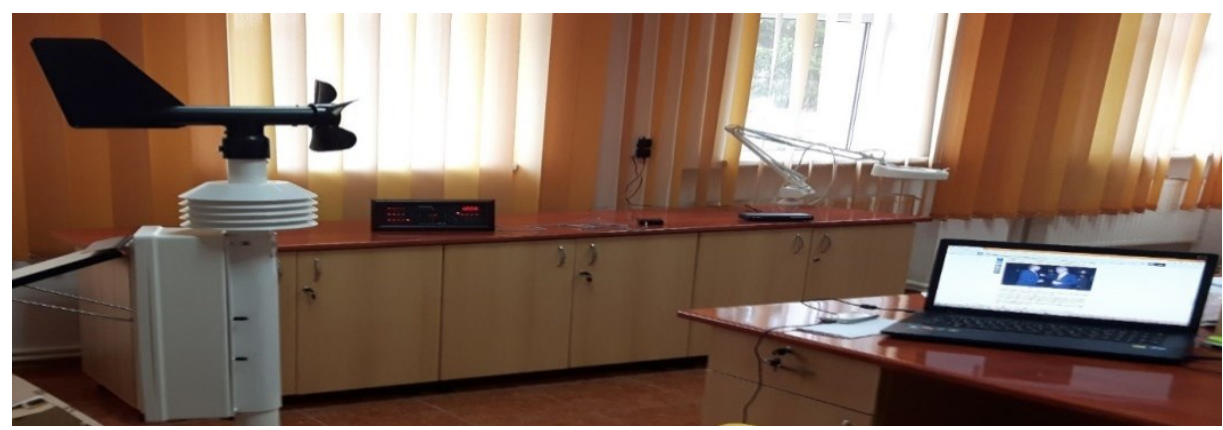

Fig. 1. Performant multifunction device for monitoring and recording parameters of microclimate

\subsection{Case Study}

In order to assess how is the compliance of the fireworks functioning in agreement with the legislative requirements and harmonized applicable method standards, following is an example of applying the procedure INSEMEX GLI-PI-98 on a Battery of shot tubes F2, as can be seen from figure 2 . 


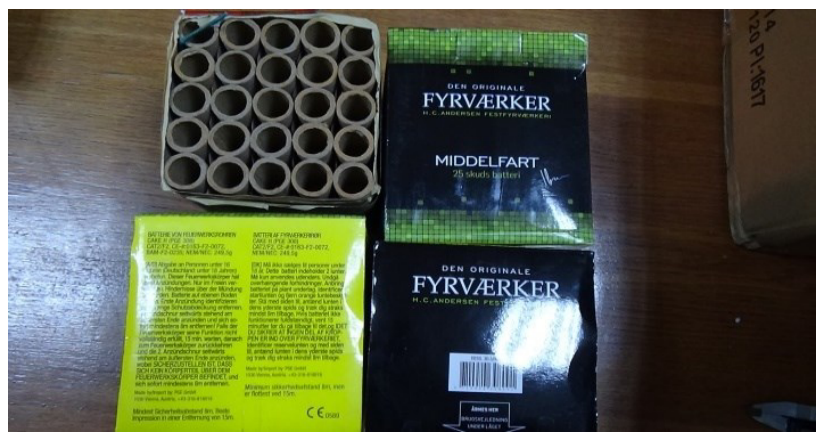

Fig. 2. Battery of shot tubes F2

The test methods have been conducted according to INSEMEX testing procedure GLIPI-98 which is based on EN 15947-4, as can be seen from table 1.

Table 1. Test Requirements - Verification

\begin{tabular}{|c|c|c|}
\hline No & $\begin{array}{l}\text { Points required } \\
\text { by client from } \\
\text { EN 15947-5:2010 }\end{array}$ & $\begin{array}{c}\text { Tests which will be } \\
\text { performed } \\
\text { by INSEMEX from } \\
\text { EN 15947-4:2010 } \\
\end{array}$ \\
\hline 1. & $\begin{array}{l}\text { 4.1.1 - Construction materials } \\
\text { - General requirements - Critical }\end{array}$ & Visual examination \\
\hline 2. & $\begin{array}{l}\text { 4.1.2 - Construction materials } \\
\text { - Specific requirements - Critical }\end{array}$ & Visual examination \\
\hline 3. & $\begin{array}{l}4.3 \text { - Permitted elements in batteries } \\
\text { and combinations - Major }\end{array}$ & Visual examination \\
\hline 4. & $\begin{array}{l}6.2 \text { - Protection of initial fuse - } \\
\text { Major }\end{array}$ & Visual examination \\
\hline 5. & $\begin{array}{l}6.3 \text { - Attachment of means of } \\
\text { ignition - Major }\end{array}$ & 6.1.6 - Fixing the ignition fuse \\
\hline 6. & $\begin{array}{l}\text { 6.4.1 - Start time and duration of } \\
\text { burning of initial fuse - Major }\end{array}$ & $\begin{array}{l}\text { 6.6.2.1 - Ignition time } \\
\text { 6.6.2.2 - Initial fuse time }\end{array}$ \\
\hline 7 & $\begin{array}{l}\text { 6.4.2. Invisible burning of Roman } \\
\text { Candles; Ignition time of sparkles - } \\
\text { Major }\end{array}$ & 6.6.2.3 - Invisible burning time \\
\hline 8. & $\begin{array}{l}\text { 7.1.2.1 - Integrity - General } \\
\text { requirements - Major }\end{array}$ & Visual examination \\
\hline 9. & $\begin{array}{l}\text { 7.1.2.2 - Integrity - Specific } \\
\text { requirements - Major }\end{array}$ & Visual examination \\
\hline 10. & $\begin{array}{l}\text { 7.1.3 - Stabilization of flight - } \\
\text { Critical }\end{array}$ & Visual examination \\
\hline 11. & 7.2.2 - Functioning - Major & 6.17 - Function test \\
\hline 12. & 7.2.3 - Angle of ascent or flight & $\begin{array}{l}6.4-\text { Angle of ascent and } \\
\text { height of effects }\end{array}$ \\
\hline 13. & $\begin{array}{l}\text { 7.2.4 - Motion - Applies to jumping } \\
\text { ground spinners only - Major }\end{array}$ & $\begin{array}{l}\text { 6.4.3 Procedure for items other } \\
\text { than Spinners }\end{array}$ \\
\hline 14. & $\begin{array}{l}\text { 7.2.5 - Stability during functioning - } \\
\text { Critical }\end{array}$ & 6.17 - Function test \\
\hline
\end{tabular}




\begin{tabular}{|c|c|c|}
\hline No & $\begin{array}{l}\text { Points required } \\
\text { by client from } \\
\text { EN 15947-5:2010 }\end{array}$ & $\begin{array}{c}\text { Tests which will be } \\
\text { performed } \\
\text { by INSEMEX from } \\
\text { EN 15947-4:2010 }\end{array}$ \\
\hline 15. & $\begin{array}{l}\text { 7.2.6 - Height of explosion } \\
\text { - Major }\end{array}$ & $\begin{array}{l}6.4 \text { - Angle of ascent and } \\
\text { height of effects }\end{array}$ \\
\hline 16. & 7.2.7 - Sound pressure level - Major & $\begin{array}{l}6.5 \text { - Measurement of sound } \\
\text { pressure level }\end{array}$ \\
\hline 17. & $\begin{array}{l}\text { 7.2.8 - Explosions and other failures } \\
\text { - Critical }\end{array}$ & 6.17 - Function test \\
\hline 18 & $\begin{array}{l}\text { 7.2.9.-Burning or incandescent } \\
\text { matter-Major }\end{array}$ & 6.12 - Incandescent matter \\
\hline 19. & $\begin{array}{l}\text { 7.2.11 - Projected debris } \\
\text { - Major }\end{array}$ & $\begin{array}{l}6.11-\text { Projected debris } \\
\text { (outdoor) }\end{array}$ \\
\hline 20 & 7.3.2. - Plastics body - Major & Visual tracking in operation \\
\hline
\end{tabular}

\section{Results}

The results after applying testing procedure GLI-PI-98, as can be seen from table 2 .

Table 2. Test results

\begin{tabular}{|c|c|c|c|c|c|c|c|c|c|c|c|c|}
\hline \multirow{2}{*}{ No } & \multirow{2}{*}{ Description } & \multicolumn{10}{|c|}{ Sample } & \multirow{2}{*}{ Conclusions } \\
\hline & & 1 & 2 & 3 & 4 & 5 & 6 & 7 & 8 & 9 & 10 & \\
\hline 1 & $\begin{array}{l}\text { The body of the firework case shall be } \\
\text { made of paper, cardboard or plastics; } \\
\text { The base (end closures) or means of } \\
\text { fixing shall be made of non-metallic } \\
\text { material (wood, staples, nails, } \\
\text { aluminum coated foil or binding } \\
\text { wires). }\end{array}$ & $\sqrt{ }$ & $\sqrt{ }$ & $\sqrt{ }$ & $\sqrt{ }$ & $\sqrt{ }$ & $\sqrt{ }$ & $\sqrt{ }$ & $\sqrt{ }$ & $\sqrt{ }$ & $\sqrt{ }$ & $\begin{array}{c}\text { Conformity } \\
10 / 10\end{array}$ \\
\hline 2 & $\begin{array}{l}\text { For batteries of mines, Roman } \\
\text { candles or shot tubes: the tubes shall } \\
\text { have a maximum angle of } 30^{\circ} \text { to the } \\
\text { vertical }\end{array}$ & $\sqrt{ }$ & $\sqrt{ }$ & $\sqrt{ }$ & $\sqrt{ }$ & $\sqrt{ }$ & $\sqrt{ }$ & $\sqrt{ }$ & $\sqrt{ }$ & $\sqrt{ }$ & $\sqrt{ }$ & $\begin{array}{c}\text { Conformity } \\
10 / 10\end{array}$ \\
\hline 3 & $\begin{array}{l}\text { The following elements can be used } \\
\text { in batteries: bangers and flash } \\
\text { bangers, Bengal flames, crackling } \\
\text { granules, fountains, ground spinners, } \\
\text { mines, rockets (assembled in a } \\
\text { launcher), Roman candles, spinners, } \\
\text { shot tubes and wheels; }\end{array}$ & $\sqrt{ }$ & $\sqrt{ }$ & $\sqrt{ }$ & $\sqrt{ }$ & $\sqrt{ }$ & $\sqrt{ }$ & $\sqrt{ }$ & $\sqrt{ }$ & $\sqrt{ }$ & $\sqrt{ }$ & $\begin{array}{c}\text { Conformity } \\
10 / 10\end{array}$ \\
\hline 4 & $\begin{array}{l}\text { The initial fuse and reserve fuse, shall } \\
\text { be protected by an orange fuse cover, } \\
\text { a primary pack or a selection } \\
\text { pack;There shall be no exposed } \\
\text { instantaneous fuse. }\end{array}$ & $\sqrt{ }$ & $\sqrt{ }$ & $\sqrt{ }$ & $\sqrt{ }$ & $\sqrt{ }$ & $\sqrt{ }$ & $\sqrt{ }$ & $\sqrt{ }$ & $\sqrt{ }$ & $\sqrt{ }$ & $\begin{array}{c}\text { Conformity } \\
10 / 10\end{array}$ \\
\hline 5 & $\begin{array}{l}\text { Using the timing device, determine } \\
\text { and record the time until the initial } \\
\text { fuse becomes detached. If this time is } \\
\text { longer than } 10 \mathrm{~s} \text { stop the test and } \\
\text { record as "longer than } 10 \mathrm{~s} \text {. }\end{array}$ & $\sqrt{ }$ & $\sqrt{ }$ & $\sqrt{ }$ & $\sqrt{ }$ & $\sqrt{ }$ & $\sqrt{ }$ & $\sqrt{ }$ & $\sqrt{ }$ & $\sqrt{ }$ & $\sqrt{ }$ & $\begin{array}{c}\text { Conformity } \\
10 / 10\end{array}$ \\
\hline
\end{tabular}




\begin{tabular}{|c|c|c|c|c|c|c|c|c|c|c|c|c|}
\hline \multirow{2}{*}{ No } & \multirow{2}{*}{ Description } & \multicolumn{10}{|c|}{ Sample } & \multirow{2}{*}{ Conclusions } \\
\hline & & 1 & 2 & 3 & 4 & 5 & 6 & 7 & 8 & 9 & 10 & \\
\hline \multirow[t]{2}{*}{6} & $\begin{array}{l}\text { For indoor fountains of category } 1: \\
\text { the fountain shall ignite within } 5,0 \mathrm{~s} \text {. } \\
\text { Ignition time max. } 10 \mathrm{~s} \text {; Initial fuse } \\
\text { must be visible and must be indicated } \\
\text { by labeling / instructions; }\end{array}$ & $1 \mathrm{~s}$ & $1 \mathrm{~s}$ & $2 \mathrm{~s}$ & $1 \mathrm{~s}$ & $1 \mathrm{~s}$ & $1 \mathrm{~s}$ & $1 \mathrm{~s}$ & $2 \mathrm{~s}$ & $1 \mathrm{~s}$ & $1 \mathrm{~s}$ & $\begin{array}{c}\text { Conformity } \\
10 / 10\end{array}$ \\
\hline & $\begin{array}{l}\text { Duration of burning of initial fuse } 3- \\
8 \mathrm{~s} \text { cat } 1 \text { and } 2 ; \text { Duration of burning } \\
\text { of initial fuse } 5-13 \mathrm{~s} \text { cat } 3 \text {. }\end{array}$ & \begin{tabular}{|l|}
$\infty$ \\
$\infty$ \\
0 \\
0 \\
0
\end{tabular} & $\begin{array}{l}n \\
0 \\
0 \\
0\end{array}$ & \begin{tabular}{l|}
$n$ \\
Zै \\
0 \\
0
\end{tabular} & \begin{tabular}{l}
$n$ \\
\multirow{2}{n}{} \\
0 \\
0
\end{tabular} & $\begin{array}{l}n \\
2 \\
0 \\
0\end{array}$ & $\begin{array}{l}n \\
2 \\
n \\
0\end{array}$ & $\underbrace{+}_{0}$ & 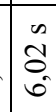 & $\begin{array}{l}n \\
n \\
n \\
0\end{array}$ & $\begin{array}{l}\infty \\
\infty \\
0 \\
0 \\
0\end{array}$ & $\begin{array}{l}\text { Conformity } \\
10 / 10\end{array}$ \\
\hline 7. & $\begin{array}{l}\text { The period of invisibleburning } \\
\text { occurring after the preliminary effect } \\
\text { shall not exceed } 5,0 \mathrm{~s} \text { (cat. 2) or } 10,0 \\
\text { s (cat. 3). }\end{array}$ & $\overleftrightarrow{Z}$ & 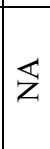 & $\overleftrightarrow{Z}$ & $\mathbb{Z}$ & $\overleftrightarrow{Z}$ & $\overleftrightarrow{z}$ & $\overleftrightarrow{Z}$ & 艺 & 艺 & $\overleftrightarrow{Z}$ & NA \\
\hline 8 & $\begin{array}{l}\text { There shall be no holes, splits, dents } \\
\text { or bulges in the body of the firework } \\
\text { case, except those technically } \\
\text { necessary for the correct functioning } \\
\text { of the firework. }\end{array}$ & $\sqrt{ }$ & $\sqrt{ }$ & $\sqrt{ }$ & $\sqrt{ }$ & $\sqrt{ }$ & $\sqrt{ }$ & $\sqrt{ }$ & $\sqrt{ }$ & $\sqrt{ }$ & $\sqrt{ }$ & $\begin{array}{l}\text { Conformity } \\
10 / 10\end{array}$ \\
\hline 9 & $\begin{array}{l}\text { Each individual element shall be } \\
\text { securely attached, other than by the } \\
\text { transmitting fuse(s) alone, to the other } \\
\text { elements or to the framework. For a } \\
\text { battery of rockets this requirement } \\
\text { shall apply to the rocket launchers, } \\
\text { not to the rockets; Elements in banger } \\
\text { batteries and flash banger batteries } \\
\text { may be joined entirely by the } \\
\text { transmitting fuse only if it is } \\
\text { sufficient to keep the elements joined } \\
\text { together during normal handling. }\end{array}$ & $\sqrt{ }$ & $\sqrt{ }$ & $\sqrt{ }$ & $\sqrt{ }$ & $\sqrt{ }$ & $\sqrt{ }$ & $\sqrt{ }$ & $\sqrt{ }$ & $\sqrt{ }$ & $\sqrt{ }$ & $\begin{array}{c}\text { Conformity } \\
10 / 10\end{array}$ \\
\hline 10 & $\begin{array}{l}\text { The article shall be fitted with a stick } \\
\text { or sticks as a means of stabilisation }\end{array}$ & $\overleftrightarrow{z}$ & $\overleftrightarrow{Z}$ & 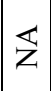 & $\overleftrightarrow{z}$ & 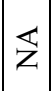 & $\overleftrightarrow{Z}$ & 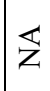 & $\overleftrightarrow{\mathrm{z}}$ & $\overleftrightarrow{z}$ & $\overleftrightarrow{z}$ & NA \\
\hline 11 & $\begin{array}{l}\text { All pyrotechnic units functioned } \\
\text { completely; The related principal } \\
\text { effect; No explosion or rupture occurs } \\
\text { during function; The elements of the } \\
\text { batteries and combinations are } \\
\text { attached securely. }\end{array}$ & $\sqrt{ }$ & $\sqrt{ }$ & $\sqrt{ }$ & $\sqrt{ }$ & $\sqrt{ }$ & $\sqrt{ }$ & $\sqrt{ }$ & $\sqrt{ }$ & $\sqrt{ }$ & $\sqrt{ }$ & $\begin{array}{c}\text { Conformity } \\
10 / 10\end{array}$ \\
\hline 12 & $\begin{array}{l}\text { For rockets: the angle of flight of the } \\
\text { rockets shall not exceed } 15^{\circ} \text { to the } \\
\text { vertical up to a height of } 20 \mathrm{~m} \text { above } \\
\text { ground. }\end{array}$ & $\overleftrightarrow{Z}$ & $\overleftrightarrow{Z}$ & $\overleftrightarrow{Z}$ & 艺 & $\overleftrightarrow{Z}$ & $\overleftrightarrow{Z}$ & $\overleftrightarrow{z}$ & $\overleftrightarrow{z}$ & $\overleftrightarrow{Z}$ & $\overleftrightarrow{Z}$ & NA \\
\hline 13 & $\begin{array}{l}\text { The article shall not move more than } \\
8,0 \mathrm{~m} \text { away from the testing point; the } \\
\text { height of ascent shall be not greater } \\
\text { than } 3 \mathrm{~m} \text {. }\end{array}$ & 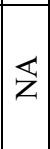 & $\overleftrightarrow{z}$ & $\mathbb{z}$ & $\overleftrightarrow{z}$ & $\overleftrightarrow{z}$ & $\overleftrightarrow{Z}$ & $\overleftrightarrow{z}$ & $\overleftrightarrow{z}$ & $\overleftrightarrow{z}$ & $\overleftrightarrow{z}$ & NA \\
\hline 14 & $\begin{array}{l}\text { Shall remain upright whilst } \\
\text { functioning:- batteries }\end{array}$ & $\sqrt{ }$ & $\mathbf{x}$ & $\sqrt{ }$ & $\sqrt{ }$ & $\sqrt{ }$ & $\mathbf{x}$ & $\sqrt{ }$ & $\sqrt{ }$ & $\sqrt{ }$ & $\sqrt{ }$ & $\begin{array}{c}\text { Conformity } \\
\mathbf{8 / 1 0}\end{array}$ \\
\hline 15 & $\begin{array}{l}\text { No explosion shall occur below a } \\
\text { height of } 8 \mathrm{~m} \text {. }\end{array}$ & $\overleftrightarrow{Z}$ & $\overleftrightarrow{Z}$ & $\overleftrightarrow{Z}$ & $\overleftrightarrow{Z}$ & $\overleftrightarrow{Z}$ & $\overleftrightarrow{Z}$ & 艺 & $\overleftrightarrow{z}$ & $\overleftrightarrow{Z}$ & 飞 & NA \\
\hline
\end{tabular}




\begin{tabular}{|c|c|c|c|c|c|c|c|c|c|c|c|c|}
\hline \multirow{2}{*}{ No } & \multirow{2}{*}{ Description } & \multicolumn{10}{|c|}{ Sample } & \multirow{2}{*}{ Conclusions } \\
\hline & & 1 & 2 & 3 & 4 & 5 & 6 & 7 & 8 & 9 & 10 & \\
\hline 16 & $\begin{array}{l}\text { Max. } 120 \mathrm{~dB} \text { for category } 2, \text { the } \\
\text { microphone is set up at a horizontal } \\
\text { distance of } 8,0 \mathrm{~m} \text { from the testing } \\
\text { point; }\end{array}$ & $\begin{array}{l}\eta \\
z \\
n \\
\pm \\
=\end{array}$ & 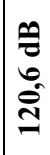 & 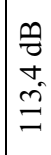 & $\begin{array}{l}\eta \\
n \\
n \\
=\end{array}$ & $\begin{array}{l}\mathscr{\eta} \\
\infty \\
\infty \\
= \\
=\end{array}$ & 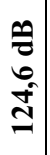 & 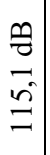 & $\begin{array}{l}q \\
\tilde{z} \\
0 \\
\dot{ \pm} \\
=\end{array}$ & 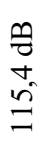 & $\begin{array}{l}\eta \\
\eta \\
2 \\
\pm \\
=\end{array}$ & $\begin{array}{l}\text { Conformity } \\
\mathbf{8} / \mathbf{1 0}\end{array}$ \\
\hline 17 & $\begin{array}{l}\text { For batteries and combinations: the } \\
\text { article shall not produce an explosion } \\
\text { damaging the integrity of the } \\
\text { firework. No explosion or rupture } \\
\text { occurs during function. }\end{array}$ & $\sqrt{ }$ & $\sqrt{ }$ & $\sqrt{ }$ & $\sqrt{ }$ & $\sqrt{ }$ & $\sqrt{ }$ & $\sqrt{ }$ & $\sqrt{ }$ & $\sqrt{ }$ & $\sqrt{ }$ & $\begin{array}{c}\text { Conformity } \\
10 / 10\end{array}$ \\
\hline 18 & $\begin{array}{l}\text { No burning or incandescent matter } \\
\text { shall fall to the ground more than } 1,0 \\
\mathrm{~m} \text { (category } 1), 8,0 \mathrm{~m} \text { (category } 2 \text { ) or } \\
15,0 \mathrm{~m} \text { (category } 3 \text { ) from the testing } \\
\text { point }\end{array}$ & $\sqrt{ }$ & $\mathbf{x}$ & $\sqrt{ }$ & $\sqrt{ }$ & $\sqrt{ }$ & $\mathbf{x}$ & $\sqrt{ }$ & $\sqrt{ }$ & $\sqrt{ }$ & $\sqrt{ }$ & $\begin{array}{c}\text { Conformity } \\
\mathbf{8 / 1 0}\end{array}$ \\
\hline 19 & $\begin{array}{l}\text { Record whether any debris is } \\
\text { projected laterally more than the } \\
\text { relevant safety distance ( } 1 \mathrm{~m} \text { cat. } 1,8 \\
\text { m cat. } 2 \text { and } 15 \mathrm{~m} \text { cat. } 3 \text { ) }\end{array}$ & $\sqrt{ }$ & $\sqrt{ }$ & $\sqrt{ }$ & $\sqrt{ }$ & $\sqrt{ }$ & $\sqrt{ }$ & $\sqrt{ }$ & $\sqrt{ }$ & $\sqrt{ }$ & $\sqrt{ }$ & $\begin{array}{c}\text { Conformity } \\
10 / 10\end{array}$ \\
\hline 20 & $\begin{array}{l}\text { If the article has a plastics body, the } \\
\text { body shall not splinter. }\end{array}$ & 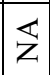 & 飞 & $\overleftrightarrow{Z}$ & 飞 & $\overleftrightarrow{Z}$ & $\overleftrightarrow{Z}$ & $\overleftrightarrow{Z}$ & $\overleftrightarrow{Z}$ & 艺 & 艺 & NA \\
\hline
\end{tabular}

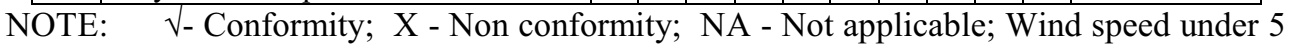
$\mathrm{m} / \mathrm{s}$ at function test period.

Analysis of ambiental and weather effects on the functioning of fireworks (F1, F2, F3, F4) Situation on functioning behaviour of fireworks F2, F3 and F4 it is highly variable, in what it means micro-climate conditions of the use of these products in question is tested for evaluation.

Thus, the rate of combustion and the intensity of emission of heat energy is directly proportional to the temperature variation, or kinetic energy, high humidity also adversely affect the functioning of the product slowing down the speed of combustion or misfire situation (stop working); but pressure is also an influencing factor, in the sense that its growth also leads to higher burning velocity. One major factor is relatively quite difficult to monitor at operation, the influence of wind that occurs mainly on deviation of the upward trajectory of pyrotechnic articles, the noise, and the spread of toxic fumes downwind outside the safety zone. During operation, the wind speed vector changes randomly and assess the influence of global trajectory and wind speed is difficult to provide and quantify.

By analysing the specific operating parameters of these types of fireworks, could be established on scientific bases for each type / category of fireworks tested the possible influence of external factors specific of environment test and work which can affect their smooth functioning, among which may be mentioned in particular: the wind (the intensity and direction), ambient temperature, humidity, pressure, nature and consistency / quality of soil / platform on which are placed the fireworks before the test of its functioning etc.

\section{Conclusions}

For a better understanding of how to evaluate the ambiental effects and weather on the functioning of these types of fireworks, it was considered the knowledge / documentation of alternative solutions given in the informative annexes contained in the applicable standards 
method, in view of solving the whole range of issues related to the testing of these types of fireworks.

In order to implement an integrated and comprehensive solutions to ensure the measurements and determinations of fireworks displaying it was purchase a performant multifunction device for monitoring and recording parameters of microclimate with incorporated software according to European applicable harmonized standards, type RainWise CC-3000, produced in the USA.

Following the test operation of the fireworks it was found that microclimate factors have a direct influence on their proper functioning, affecting the accuracy of outcome indicators both in terms of absolute value and is required a correction given by statistical uncertainty and in terms of the appreciation of their quality, influencing how perception often in situations of unfavourable ambiental and weather effects, is one eronated.

\section{References}

1. R. I. Moraru, G. B. Băbuţ, L. I. Cioca, Environmental Engineering and Management Journal, 13, (6), 1371-1376 (2014)

2. L. Ivaşcu, L. I. Cioca, The 2nd International Conference on Psychology, Management and Social Science, Psychology, Management and Social Science, Shenzhen, China, Book Series: Advances in Education Research, 49, 77-80 (2014)

3. C. Jitea, Research on aspects related to structuring exercise and psychosocial training to optimize the process of intervention and rescue personnel in toxic / flammable / explosive environments PN 074502 30, NRDI INSEMEX

4. *** Directive 2013/29/EU of the European Parliament and of the Council of 12 June 2013 on the harmonisation of the laws of the Member States relating to the making available on the market of pyrotechnic articles. 